\title{
Fagoterapia, alternativa para el control de las infecciones bacterianas. Perspectivas en Colombia
}

\author{
Prada-Peñaranda Catalina ${ }^{1}$, Holguín-Moreno Angela-Victoria ${ }^{1}$, González-Barrios Andrés- \\ Fernando $^{2}$, Vives-Flórez Martha-Josefina ${ }^{1 凶}$
}

Phage-therapy, an alternative to control bacterial infections. Perspectives in Colombia

\begin{abstract}
Bacteria easily acquire resistance to antimicrobial agents and this reduces the number of effective antibiotics available to treat bacterial infections. Food contamination by bacteria also generates important economic losses and health risks. Products for human consumption must be free of antibiotics used in clinical treatments, and the control of bacteria with antimicrobials is strictly regulated; however, there is a lack of development of new antibiotics. As a result, the development of new antimicrobial strategies is vital. Viruses that infect bacteria called bacteriophages (phages) have been proposed as an alternative treatment in an approach known as phage-therapy. Several studies have evaluated and demonstrated their effectiveness against pathogenic bacteria; currently, there are private companies dedicated to the development of new products based on phage cocktails, to control some bacterial infections. In Colombia, there is no previous information about the use of phages, but phage-therapy represents a great opportunity to use the diversity of the native microbiota. In this review, we present the perspectives for phage-therapy in Colombia as a treatment against bacterial infections.
\end{abstract}

Keywords: bacteriophages; resistance to antibiotics; phage-therapy; Colombia.

Edited by Alberto Acosta $\square$

1. Centro de Investigaciones Microbiológicas (CIMIC), Departamento

de Ciencias Biológicas, Universidad de los Andes, Bogotá Colombia.

2 Grupo de Diseño de Productos y Procesos (GDPP), Departamento de Ingeniería Química, Universidad de los Andes, Bogotá Colombia.

Received: 29-05-2014 Accepted: 10-07-2014

Published on line: 11-08-2014

Citation: Prada-Peñaranda C, Holguín-Moreno AV, González-Barrios AF, Vives-Flórez MJ (2015) Fagoterapia, alternativa para el control de las infecciones bacterianas. Perspectivas en Colombia. Universitas Scientiarum 20(1): 43-60 doi: 10.11144/Javeriana.SC20-1.faci

Funding: Banco Santander por la financiación recibida a través del Premio Santander Emprendimiento Ciencias e Innovación 2010; Universidad de los Andes.

Electronic supplementary material: N/A

\section{Introducción}

Resistencia bacteriana a los antimicrobianos y su impacto en la salud

Las enfermedades infecciosas están catalogadas entre las primeras causas de muerte en el mundo y, por lo tanto, son consideradas un problema de salud pública. Entre ellas, las infecciones bacterianas causan gran preocupación, dado que las bacterias adquieren día a día mayor resistencia a los antibióticos; esto ocurre por medio de diversos mecanismos fisiológicos y moleculares que les permiten a estos microorganismos adaptarse rápidamente a condiciones adversas (Prada 2008). 
La diseminación de la resistencia podría llegar a generar problemas de enormes dimensiones, como aumentos en la mortalidad, la morbilidad y los costos de atención médica. El reporte de riesgos globales emitido por el Foro Económico Mundial resaltó el problema de la resistencia bacteriana en el 2013 (World Economic Forum 2013) y la Organización Mundial de la Salud lo enfatizó en uno de sus últimos reportes (WHO 2014). Sólo en Estados Unidos se presentan 99000 muertes al año por infecciones causadas por bacterias resistentes a antibióticos adquiridas en hospitales y el costo de cuidados médicos asociados a ellas oscila entre 21 y 34 billones de dólares americanos anualmente. El problema se extiende alrededor del mundo; en Rusia el $86.3 \%$ de los hogares utilizan indiscriminadamente antibióticos; en Tanzania, África Sub-Sahariana, el número de muertes por bacterias resistentes a antibióticos duplica al número de muertes por malaria (World Economic Forum 2013). En Colombia se ha observado un incremento en el aislamiento de cepas multi-resistentes, tanto en Unidades de Cuidado Intensivo (UCI) pediátricas como en UCI de adultos; el riesgo de infecciones observado es 2 a 20 veces mayor en recién nacidos que requieren dispositivos intravasculares (INS 2009). Entre los incrementos más dramáticos se cuenta el caso de Escherichia coli productora de beta-lactamasas de espectro extendido (BLEE), con un aumento del 3\% entre el 2012 y el 2013 (GREBO 2013).

Se ha postulado que el incremento en la resistencia bacteriana se debe al uso inapropiado de los antibióticos (Karunasagar 2012); situaciones comunes como no completar las dosis prescritas o prescripciones médicas innecesarias han hecho que hoy en día existan infecciones bacterianas para las cuales ya no existe un antibiótico eficaz. Este panorama ha llevado a que, recientemente, gobiernos y agencias de salud manifiesten la necesidad de un uso más apropiado de los antimicrobianos, y la importancia de desarrollar nuevos agentes antibacterianos (Prada 2008, Editorial 2013).

Sin embargo, una realidad del mundo farmacéutico es la falta de investigación y desarrollo de nuevas moléculas con actividad antibiótica. Desde 1987 no hay resultados exitosos en este campo (WHO 2014), situación posiblemente asociada a que la industria farmacéutica ha enfocado sus esfuerzos hacia el desarrollo de tratamientos para enfermedades crónicas como la diabetes y la hipertensión, que aseguran el retorno de las inversiones ya que son requeridos por los pacientes por largos periodos de tiempo. Además, las barreras regulatorias hacen que las pequeñas y medianas compañías farmacéuticas no puedan realizar todas las pruebas ni logren cumplir los requisitos exigidos para obtener licencias para sus productos (Davies \& Davies 2010, World Economic Forum 2013, Yonath 2013). En este sentido, el Foro Mundial hizo un fuerte llamado a la sociedad, los gobiernos y las entidades de salud para adelantar esfuerzos que permitan entender la resistencia bacteriana a múltiples antibióticos y para desarrollar tratamientos alternativos.

El origen de la resistencia a los antibióticos se extiende más allá del uso inadecuado en humanos, ya que existe también un manejo indiscriminado de estas sustancias por parte de las industrias alimenticias. En los sectores industriales de producción animal para consumo humano, los antibióticos permitidos son escasos y en ocasiones no se encuentra un tratamiento eficiente para el control y prevención de las bacterias patógenas (Philips et al. 2004, Editorial 2013). No obstante, hay estudios que indican que más del $80 \%$ de los antibióticos vendidos en los Estados Unidos y por lo menos el $50 \%$ de aquellos producidos en China van dirigidos como promotores de crecimiento a animales de consumo humano tales como cerdos, pollos y vacas; la inclusión de dichos promotores reduce la cantidad de alimento que se suministra e induce un aumento en el peso del animal y, en consecuencia, mayor rendimiento económico para los productores (Levin Institute 2014). Lo anterior representa una situación bastante delicada y peligrosa, dado que al ser utilizados estos antibióticos en productos destinados al consumo humano, las bacterias que viven en los animales adquieren resistencia a los antibióticos y esta resistencia puede ser transferida a las bacterias patógenas humanas (Donado-Godoy 2010).

A nivel mundial se han incrementado las restricciones al uso de antibióticos en los alimentos y se han diseñado normas y sistemas para el control de las mismas. En Estados Unidos, la Food and Drug Administration (FDA) ha realizado esfuerzos desde hace alrededor de 40 años para regular el uso de antibióticos en los animales (Levin Institute 2014). En Colombia, la resolución No. 1966 del 5 de Septiembre de 1984 del 
Instituto Colombiano Agropecuario (ICA) permite el uso de sustancias antimicrobianas como promotores de crecimiento o mejoradores de la eficiencia alimentaria siempre y cuando estos no coincidan con los utilizados con fines terapéuticos en medicina humana. El problema radica en que los llamados promotores de crecimiento son o tienen entre sus componentes antibióticos de amplio espectro, que pueden llegar a generar resistencia cruzada frente a antibióticos usados en medicina; el continuo incremento del uso indiscriminado de estas sustancias puede tener serios impactos en la salud humana y animal (Gómez 1984, Ríos 2004). El país importa anualmente antibióticos por un monto aproximado de USD \$27.432.000 (DNP 2014), aunque no es posible discriminar en esta cifra cuánto se destina para uso en medicina humana, medicina animal o promoción del crecimiento.

Colombia empezó a prestar atención a esta problemática recientemente; el país acogió los Límites de Residuos Máximos (LMRs) de la lista de fármacos regulados por el Codex Alimentarius (Lozano 2008, Márquez 2008) como una de las medidas necesarias para que los sectores gubernamental, académico y de investigación puedan conocer y controlar la residualidad de fármacos y otras sustancias en los alimentos de origen animal.

\section{Bacterias resistentes, producción animal y salud humana}

Una de las problemáticas mundiales relacionadas con infecciones bacterianas y resistencia a antimicrobianos es la salmonelosis, infección causada por Salmonella spp. y considerada una zoonosis asociada principalmente con productos de la cadena avícola. Las bacterias causantes son resistentes a los antibióticos de primera generación (antibióticos de baja toxicidad, económicos y fáciles de conseguir), por lo que los animales ya no pueden ser tratados con ellos. Cuando las infecciones no pueden ser tratadas con esta clase de antibióticos, el siguiente paso es utilizar antibióticos de segunda generación, que tienen mayor costo o mayor grado de toxicidad (Donado-Godoy 2010). Su uso genera la aparición de residuos en la carne de pollo que será consumida por las personas, favoreciendo así la selección de bacterias resistentes en los humanos (Lozano 2008).
Además de los tratamientos con antibióticos, para el control de Salmonella en las granjas de pollos se utilizan estrategias como la aplicación de agua clorada en aerosol, tratamientos físicos como lavados al vapor, calor seco y luz ultravioleta en planta de producción y beneficio, el uso de aditivos químicos en el alimento de los animales (Whichard 2000, Atterbury et al. 2007, García et al. 2008) y vacunas (Vandeplas et al. 2010) suministradas en las primeras semanas de vida. Se han usado vacunas con el patógeno muerto, que han mostrado una eficiencia variable; y vacunas con el patógeno atenuado, en las cuales el patógeno se encuentra viable pero con virulencia reducida. Con las vacunas atenuadas se utiliza generalmente una sola dosis, que estimula una respuesta inmunológica rápida, fuerte y duradera. Sin embargo, la inactivación se realiza de manera inespecífica con formol o con calor y, dada la alta diversidad antigénica entre los diferentes serotipos de Salmonella, no siempre el producto final confiere inmunidad. Por otro lado, los microorganismos atenuados aún tienen cierto grado de virulencia o pueden revertir su estado, con lo cual existe la posibilidad de volver a generar la enfermedad (Zhao 1967, WHO 2013). En resumen, a pesar de todas las alternativas de prevención y control, la salmonelosis sigue siendo un problema zoonótico en el mundo.

Una situación similar se presenta en la industria camaronera. La producción y comercialización de camarón es una actividad reciente a nivel mundial; entre los mariscos, el camarón es el de mayor consumo, siendo la especie más cultivada el camarón blanco del Pacífico, Litopenaeus vannamei $(92.6 \%$ de la producción camaronera mundial). El cultivo de L. vannamei se ve afectado por diferentes bacterias, como Pseudomonas spp. y Vibrio spp. (Newmark et al. 2009). En Colombia, además de las anteriores, también se han registrado infecciones causadas por la bacteria Bacillus licheniformis, responsable de una elevada mortalidad y con un alto impacto en la economía de las empresas del sector acuícola (Salazar \& Guiza datos no publicados).

Las infecciones bacterianas ocurren en piscinas y tanques de maduración. El uso de vacunas no es una opción viable, ya que los camarones poseen un sistema inmune que no les permite crear inmunidad. Existe también la tecnología de bioflocs que ofrece el control de las infecciones con buenos resultados pero 
también variables (Hargreaves 2013). En la práctica, el control de las infecciones en Colombia se realiza principalmente por medio de estrategias de manejo del cultivo; entre los métodos de control está el uso de constantes recambios de agua, cuyo objetivo es bajar la salinidad para desmejorar las condiciones para la bacteria y, en lo posible, disminuir la cantidad de animales infectados por metro cuadrado; esta estrategia es efectiva al inicio de una infección pero es muy dispendiosa. En cuanto a tratamientos con antibióticos, solo se permite el uso de oxitetraciclina y únicamente en pequeñas cantidades de tal forma que no exceda una concentración máxima de 10 ppm. Se ha reportado resistencia a este antibiótico en $B$. licheniformis, Vibrio spp. y Pseudomonas spp. (Salazar \& Guiza datos no publicados). Además, el sistema de entrega del antibiótico supone un reto importante, pues por el gran volumen de agua, se requerirían cantidades excesivas del fármaco, lo cual generaría altos costos; a esto se suma que no es viable suministrarlo en el alimento ya que el animal enfermo deja de comer.

Aunque existe una diversidad de posibilidades para la prevención y el tratamiento de las infecciones bacterianas, tanto en personas, animales como en plantas, y en otras aplicaciones industriales, ninguna de ellas ofrece en realidad una solución permanente y completa. Por lo tanto es evidente la necesidad de nuevas estrategias para combatir las infecciones que no pueden ser controladas con los medios disponibles actualmente. Una de estas alternativas es la fagoterapia, tema central de la presente revisión.

\section{Los bacteriófagos}

La fagoterapia es un tratamiento basado en la actividad bactericidadelos bacteriófagos(fagos), virus específicos de las bacterias. Los fagos reconocen la superficie de la célula bacteriana con alta especificidad, inyectan su ADN o ARN, y se multiplican y ensamblan dentro de la bacteria, para finalmente romper la célula y liberar su progenie, que infectará nuevas células bacterianas. El número de fagos crece de forma exponencial, por lo cual su mayor efecto es en el sitio de infección. Además, la selección de nuevos fagos es un proceso relativamente rápido (Sulakvelidze et al. 2001). La terapia con fagos se propuso desde el descubrimiento de los mismos y se ha desarrollado en países como
República de Georgia, Polonia, Rusia, y la antigua Alemania del este; sin embargo, después del boom del descubrimiento de la penicilina y otros antibióticos, la investigación en fagoterapia en Europa occidental y América fue abandonada. En los últimos años, con el incremento en la frecuencia de aparición de cepas multirresistentes y panresistentes a antibióticos, los investigadores han retomado el interés en el desarrollo de fagoterapia y su implementación para el control de la contaminación e infecciones bacterianas en diversos campos (Kutter \& Sulakvelidze 2005).

La palabra bacteriófago proviene de "bacteria" y "fagein" (del griego comer o devorar) propuesta por Felix d'Herelle (Sulakvelidze et al. 2001). Los bacteriófagos o fagos, virus que infectan bacterias disminuyendo su población, son parásitos obligados que utilizan la maquinaria de su hospedero bacteriano para replicarse (Monk et al. 2010). Fueron observados por primera vez en 1896 y 1898 por el británico Ernest Hankin y el ruso Gamaleya, respectivamente, quienes los describieron como una sustancia no identificada con posible actividad antibacteriana. Descritos de manera independiente por el británico Frederick Twort en 1915 y por el francocanadiense Felix d'Herelle en 1917, Twort fue el primero en reportar su capacidad lítica (Kutter \& Sulakvelidze 2005, Monk et al. 2010); sin embargo, por diversas circunstancias, no continuó con sus experimentos. Los bacteriófagos fueron oficialmente nombrados en 1917 por d'Herelle durante sus investigaciones en el Instituto Pasteur de Paris, mientras estudiaba la crisis de disentería en soldados franceses (Kutter \& Sulakvelidze 2005). D’Herelle, al igual de Twort, demostró que las bacterias eran destruidas, hecho evidenciado por la aparición de pequeños halos traslúcidos en la superficie de los medios de cultivo. Sus observaciones fueron publicadas en un artículo titulado "Sobre un microbio invisible antagonista de los bacilos de la disentería" (Segundo et al. 2007). Felix d'Herelle, junto con George Eliava, co-fundaron en 1933 un instituto para la investigación en fagos en la República de Georgia (McAuliffe et al. 2007), instituto que sobrevive hasta nuestros días (http://www.eliava-institute.org/).

La identificación y caracterización son los pasos iniciales en cualquier investigación sobre los fagos. La taxonomía de los bacteriófagos ha sido un tema de discusión constante desde su descubrimiento. 
Dada la naturaleza ultramicroscópica de los fagos, las herramientas tecnológicas han sido fundamentales para la evolución de su clasificación. En 1966, el Congreso Internacional de Microbiología llevado a cabo en Rusia estableció el International Committee on Taxonomy of Viruses - ICTV, que desarrolló un sistema taxonómico universal para los virus (Nelson 2004). En el caso de los fagos, el sistema incluye la descripción estructural a través de microscopía electrónica y tipo de material genético (Tabla 1). De acuerdo con esta clasificación, el 90\% de los fagos descritos ha sido de ADN de doble cadena (Kutter \& Sulakvelidze 2005), con estructura convencional de cabeza en forma de icosaedro y cola; estos fagos han sido agrupados en el orden Caudovirales. El orden Caudovirales está conformado por tres familias: Myoviridae, con cola rígida, larga y contráctil; Siphoviridae, cola no contráctil, larga y flexible, y Podoviridae, cola no contráctil y corta (Monk et al. 2010). Las demás familias no se encuentran agrupadas en categorías taxonómicas superiores, y son: Microviridae, Corticoviridae, Tectiviridae, fagos de ADN con simetría cúbica; Leviviridae, Cystoviridae, fagos de ARN con simetría cúbica; Inoviridae, Lipothrixiviridae, Rudiviridae, fagos de ADN con simetría helicoidal; Plasmaviridae, Fuselloviridae, Guttaviridae, fagos de ADN pleomórficos (Ackerman datos no publicados). Con el advenimiento de las técnicas de secuenciación masiva desarrolladas en los últimos años, se ha facilitado la obtención de información confiable sobre los genomas de fagos y la incorporación del análisis genómico en el estudio de su diversidad.

El ciclo de infección viral inicia con la adsorción del fago a la bacteria susceptible. La adsorción ocurre en dos etapas, la primera reversible seguida de la irreversible. La interacción reversible es débil y alterable por cualquier cambio en el medio; la interacción irreversible es, por el contrario, mediada por estructuras o receptores específicos. Esta especificidad muestra que un fago sólo puede infectar las bacterias que tengan los receptores a los cuales el fago se pueda unir (Hughes et al. 1998, Azeredo \& Sutherland 2008). La naturaleza de los receptores varía de acuerdo con el fago: proteínas y lipopolisacáridos de la pared celular, ácidos teicoicos, flagelos y pili pueden servir como receptores (Skurnik \& Strauch 2006). En Caudovirales la unión irreversible está mediada por proteínas de la
Tabla 1. Familias de fagos y sus principales características. Las representaciones de las morfologías no se encuentran a la misma escala por lo que no son comparables entre sí. cd: cadena doble. cs: cadena sencilla

\begin{tabular}{|c|c|c|c|}
\hline Familia & $\begin{array}{l}\text { Material } \\
\text { genético }\end{array}$ & Hospedero & Morfología \\
\hline Corticoviridae & cdADN & Bacteria & \\
\hline Tectiviridae & $\mathrm{cdADN}$ & Bacteria & \\
\hline Podoviridae & cdADN & Bacteria & \\
\hline Myoviridae & $\mathrm{cdADN}$ & $\begin{array}{c}\text { Bacteria y } \\
\text { Archaea }\end{array}$ & \\
\hline Siphoviridae & $\mathrm{cdADN}$ & $\begin{array}{c}\text { Bacteria y } \\
\text { Archaea }\end{array}$ & \\
\hline Fuselloviridae & $\mathrm{cdADN}$ & Archaea & \\
\hline Guttaviridae & cdADN & Archaea & \\
\hline Lipothrixiviridae & $\operatorname{cdADN}$ & Archaea & \\
\hline Rudiviridae & cdADN & Archaea & \\
\hline Plasmaviridae & $\mathrm{cdADN}$ & Bacteria & \\
\hline $\begin{array}{l}\text { Sin familia } \\
\text { asignada } \\
\text { Salterprovirus }\end{array}$ & cdADN & & \\
\hline Microviridae & $\operatorname{csADN}$ & Bacteria & \\
\hline Inoviridae & csADN & Bacteria & $=$ \\
\hline Cystoviridae & cdARN & Bacteria & \\
\hline Leviviridae & $\operatorname{cs} A R N$ & Bacteria & \\
\hline
\end{tabular}


placa basal del fago y receptores específicos de la pared bacteriana. La velocidad y eficiencia de la adsorción son aspectos importantes que varían dependiendo del sistema fago-hospedero que se esté analizando, de factores externos y del estado fisiológico del hospedero.

Una vez lograda la unión irreversible, el material genético del fago entra a la célula bacteriana, proceso que involucra mecanismos de transferencia específica de ADN o ARN (Kutter \& Sulakvelidze 2005). Seguidamente, y dependiendo de su naturaleza, los fagos pueden realizar uno de los siguientes cuatro tipos de ciclos de vida: lítico (que finaliza con la lisis de la bacteria infectada), lisogénico (el genoma del fago es insertado en el genoma de la bacteria y no ocurre lisis inmediata) (Skurnik \& Strauch 2006), ciclo de desarrollo continuo o ciclo pseudolisogénico (Krylov 2001, Miller \& Day 2008).
En el ciclo lítico el fago se multiplica dentro de la célula bacteriana, lisándola al final del ciclo para liberar nuevos fagos (Figura 1, pasos 1 a 6); la sucesiva liberación de nuevos fagos permite la infección a nuevos hospederos de forma exponencial. Un fago virulento es aquel que realiza ciclo lítico; se adhiere a la bacteria (adsorción), inyecta su material genético dentro de la célula hospedera (penetración) desde donde dirige la expresión de los genes responsables de la replicación del genoma viral, la síntesis de nuevas partículas de fagos y la lisis posterior de la bacteria hospedera para la liberación de la progenie (Azeredo \& Sutherland 2008). La lisis es el resultado del daño en la pared celular bacteriana, causado por enzimas específicas del fago llamadas lisinas, que digieren el peptidoglucano bacteriano (Fischetti 2008, Hermoso et al. 2007).

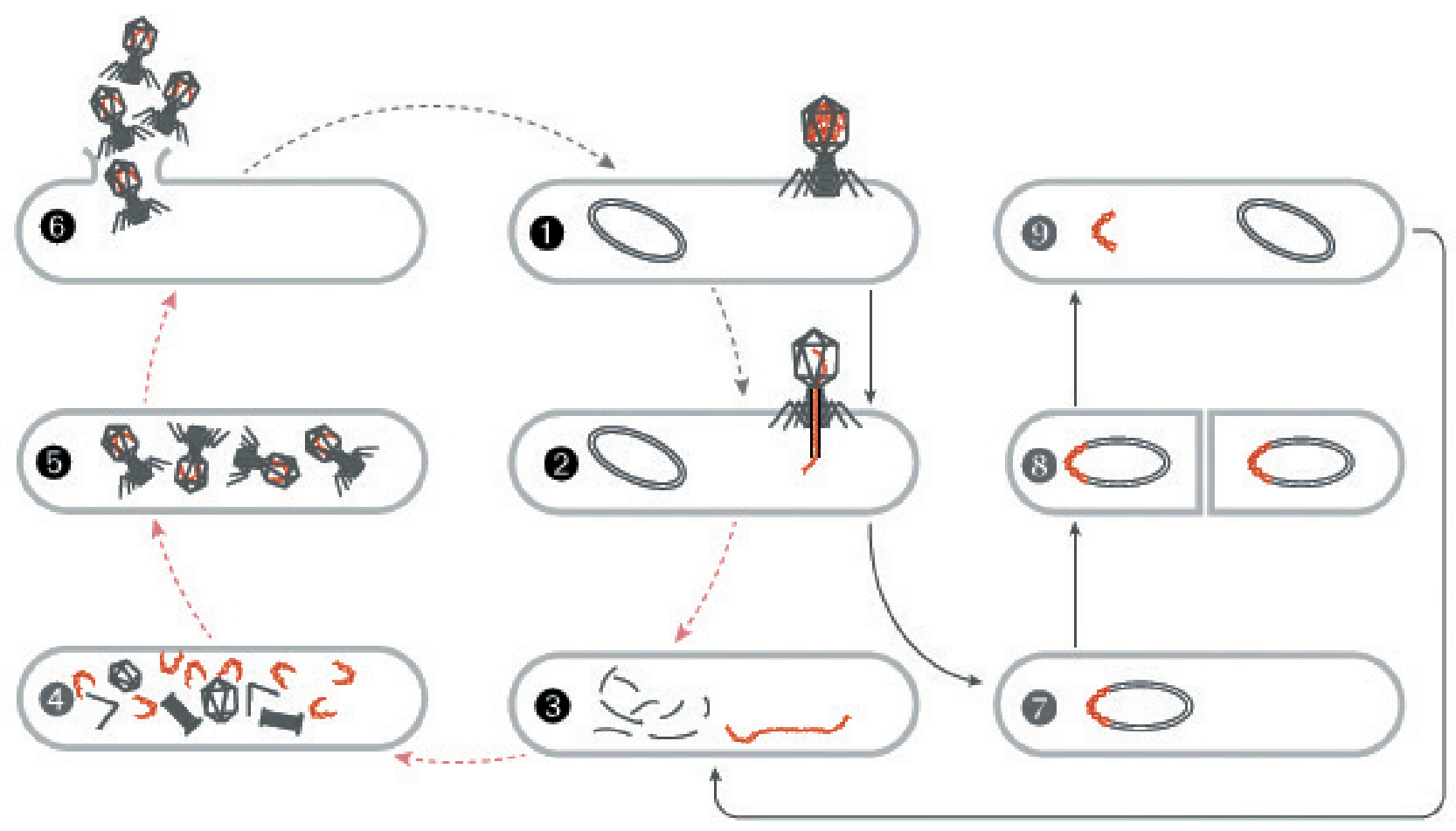

Fig 1. Ciclos lítico y lisogénico de los bacteriófagos. La figura muestra dos de los ciclos de infección que pueden llevar a cabo los fagos: el ciclo lítico (pasos 1 a 6) y el ciclo lisogénico (pasos 1 a 2 y 7 a 9). Paso 1: El fago se une a la bacteria (adsorción). Paso 2: El material genético del fago entra al citoplasma bacteriano (penetración). Paso 3: Síntesis de proteínas tempranas del fago que permiten el inicio del ciclo reproductivo del virus y detienen el metabolismo bacteriano. Paso 4: Síntesis de proteínas estructurales virales. Paso 5: Ensamblaje de estructuras virales. Paso 6: Liberación de la progenie viral. Paso 7: Formación del lisógeno, inserción del material genético del fago al cromosoma bacteriano. Paso 8: Multiplicación bacteriana con el profago en su genoma. Paso 9: Escisión del profago y activación del ciclo lítico. 
Para conocer el crecimiento poblacional de un fago y evaluar la eficiencia de su infección se realizan las curvas de "un paso" o curvas "one-step", con las que se determina el número de viriones liberados por bacteria infectada, conocido como "burst size" (B), la duración del periodo de eclipse (E) y del periodo de latencia (L) (Wang 2005, Choi et al. 2010, Park et al. 2012) (Figura 2).

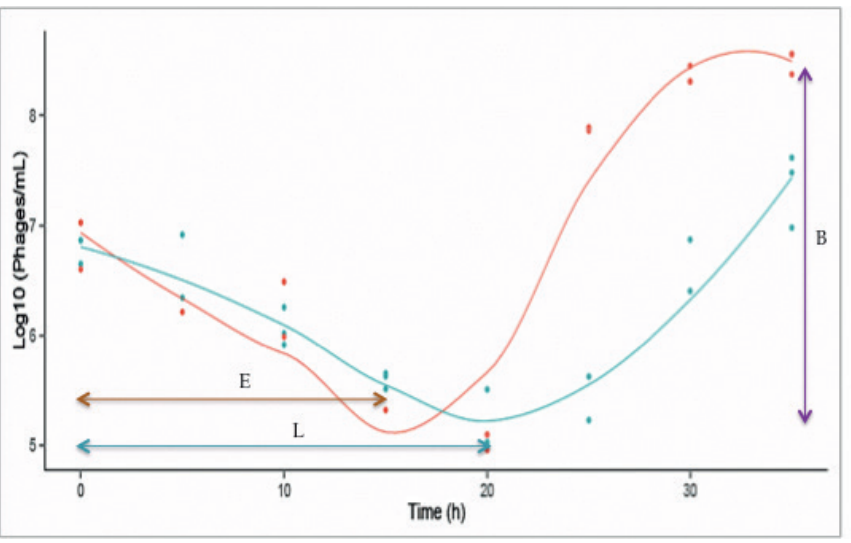

Fig 2. Curva de crecimiento de un paso o one step para un fago nativo colombiano (con permiso de Ana Paula Jiménez Sánchez) (Jiménez \& Vives 2013). El fago produce un número de viriones o "burst size" (B) de 44.12, su periodo de latencia (L) tiene una duración de 20 min y su periodo de eclipse (E) de $15 \mathrm{~min}$. Los fagos totales se muestran en la línea naranja y los fagos libres en la línea azul. El período de latencia (L) se define como el tiempo que transcurre desde la adsorción de los fagos hasta la liberación de la progenie por medio de la lisis celular bacteriana que induce el fago. El período de eclipse (E) es el periodo necesario para la producción de las partículas virales infectivas en el interior de la bacteria.

En el ciclo lisogénico, después de la adsorción y penetración, el fago no destruye a la célula hospedera. En cambio, su genoma es integrado al del hospedero y se replica conjuntamente con él (Figura 1, pasos 1 a 2, 7 a 9), generando un clon de células infectadas que pueden multiplicarse por varias generaciones. Los fagos capaces de realizar ciclo lisogénico son conocidos como temperados, y su genoma integrado al del hospedero se denomina profago (Skurnik \& Strauch 2006). El ciclo lisogénico se favorece cuando los bacteriófagos se encuentran en alta concentración con respecto al número de células, indicador que se conoce como multiplicidad de infección - MOI (por sus siglas en inglés). Cada una de las bacterias lisógenas puede eventualmente producir fagos y lisar bajo condiciones ambientales apropiadas (Figura 1, pasos 3 a 6).

Existen fagos que realizan un ciclo de desarrollo continuo. En este ciclo los fagos se forman de manera ininterrumpida en la célula hospedera, sin ocasionar lisis, y son liberados por poros específicos mientras terminan la maduración del virión. Este es el caso del bacteriófago filamentoso M13 (familia Inoviridae). La síntesis de los bacteriófagos implica una disminución en la tasa de división de las células infectadas (Krylov 2001)

Otro ciclo de vida que los bacteriófagos pueden llevar a cabo es el pseudolisogénico; este ha sido poco estudiado, porlocual sus bases moleculares y fisiológicas no son aún bien comprendidas. Fue imaginado por primera vez por Twort, y posteriormente discutido en la revisión sobre lisogenia de André Lwoffig en 1953. También fue descrito por Roming y Brodetsky en 1961, quienes exploraron la relación entre Bacillus spp. y sus fagos, aunque utilizando otra designación (Miller $\&$ Day 2008). A menudo se hace referencia a este ciclo cuando existe una producción continua de fagos en presencia de una abundante población bacteriana, coexistiendo simultáneamente una densidad celular bacteriana y viral elevada. La situación descrita es explicada por dos posibles situaciones: a) presencia de una mezcla de células bacterianas sensibles y resistentes o b) una mezcla de fagos líticos y lisogénicos (Paul et al. 2002). Se cree que la pseudolisogénesis ocurre cuando la célula hospedera se encuentra en condiciones de limitación de nutrientes, caso en el que no hay energía disponible para que el fago produzca una respuesta lítica o lisogénica. Incrementados los niveles de nutrientes para la célula hospedera, el fago puede usar la energía celular necesaria para poder realizar expresión génica, lo cual lo lleva a producir lisogenia o lisis (Miller \& Day 2008)

\section{Fagoterapia}

La fagoterapia es la aplicación de bacteriófagos para el control de bacterias patógenas (Kutter \& Sulakvelidze 2005). Los primeros ensayos utilizando este tratamiento como terapia para combatir infecciones bacterianas fueron realizados en 1919 en el Hospital 
Enfants-Malades de París por d'Herelle, quien experimentó con éxito la actividad antibacteriana de los fagos para el tratamiento de la disentería de un niño de 12 años. D’Herelle utilizó un preparado de fagos contra cepas de Shigella seleccionados específicamente para tratar al niño, quien presentaba disentería severa (10-12 deposiciones diarias con sangre). Previamente, d’Herelle mismo y varios médicos voluntarios del hospital ingirieron una dosis 100 veces mayor del preparado de fagos, con el fin de descartar cualquier efecto secundario. Se le suministraron al niño $2 \mathrm{ml}$ del preparado; horas después, el niño presentó solo tres deposiciones con sangrado y en la noche de ese día ya habían desaparecido. A los pocos días el niño estaba completamente recuperado. La eficiencia de este preparado fue corroborada al ser suministrado a tres niños más entre 3 y 10 años que presentaban disentería y quienes, también con una sola dosis, se recuperaron en 24 h (Sulakvelidze et al. 2001, Yan-Yu 2008, Goldman \& Green 2009). En otro estudio, realizado en 1921 por Richard Bruynoghe y Joseph Maisin, se utilizaron bacteriófagos para tratar infecciones estafilocócicas de piel (Sulakvelidze et al. 2001).

D'Herelle y otros investigadores continuaron sus trabajos en fagoterapia y, hacia 1930, diversas compañías iniciaron la comercialización de fagos contra bacterias patógenas. Mientras tanto, d'Herelle estableció centros de fagoterapia en diferentes países, entre los que se encontraban Estados Unidos (Eli Lilly), Francia y Georgia. Las preparaciones usadas consistían en fagos libres de bacterias, procedentes directamente de lisados en caldos de cultivo bacteriológicos de la cepa hospedera o en una base de gelatina soluble en agua (Sulakvelidze et al. 2001). Los fagos fueron usados como agentes terapéuticos en los años 1920 - 1930, época considerada como la era histórica de la fagoterapia; también durante la Segunda Guerra Mundial para combatir la disentería.

En Rusia, Polonia y Georgia las investigaciones sobre fagoterapia han continuado durante 90 años. Los fagos en esos países se han administrado de forma oral, tópica, rectal, inyectada o intravenosa (Sulakvelidze et al. 2001) sin reportes de efectos colaterales (Potera 2013).

Sin embargo, por diferentes razones, la fagoterapia fue abandonada en el mundo occidental entre 19451950, cuando aparecieron los antibióticos (Potera
2013), que llegaron a considerarse la terapia más eficaz contra las infecciones bacterianas. Las publicaciones sobre fagoterapia entre 1950 y 1980 fueron muy pocas, ya que las investigaciones relacionadas con el tema despertaban muy poco interés.

La situación cambió radicalmente cuando la terapia con antibióticos comenzó a fallar a causa de la resistencia bacteriana (Watanabe et al. 2007); a partir de este momento renace el interés en la fagoterapia en Occidente (Hermoso et al. 2007).

La fagoterapia tiene diversas ventajas al compararla con la terapia con antibióticos: 1) El número de fagos crece exponencialmente, permitiendo que esta terapia tenga su mayor efecto en el sitio de infección. Los antibióticos, en cambio, van perdiendo su efecto, puesto que a medida que actúan hay destrucción metabólica de la molécula. Un solo fago puede llegar a ser suficiente para destruir una bacteria determinada, mientras que para causar el mismo efecto utilizando antibióticos se requieren numerosas moléculas de éstos. 2) Gracias a que los fagos tienen la capacidad de mutar, se puede combatir la resistencia que podrían llegar a generar las bacterias hacia ellos; en cambio, los antibióticos siempre tienen el mismo principio activo, de manera que cuando las bacterias desarrollan resistencia, éstos quedan inservibles (Carlon 1999). 3) El tratamiento con bacteriófagos no genera efectos secundarios nocivos para humanos, animales ni plantas (Kutter \& Sulakvelidze 2005; Meipariani 2013, Kutter et al. 2010, Abedon et al. 2011), mientras que los antibióticos pueden causar alergias, desórdenes intestinales, infecciones secundarias y otros múltiples efectos adversos. Incluso se considera que los fagos tienen un efecto benéfico al estimular el sistema inmune (Kutter et al. 2010). 4) Seleccionar y producir un nuevo fago es un procedimiento relativamente rápido y económico, cuyas fases a escala laboratorio se pueden completar en términos de meses; en cambio, el desarrollo de un antibiótico toma años (Sulakvelidze et al. 2001). 5) La alta especificidad que caracteriza a los fagos hace posible que lleguen a ser incluso cepaespecíficos; la especificidad de los fagos es un aspecto ventajoso, pues con ella se limita el tratamiento a la bacteria problema, causante de la infección, sin afectar la microbiota normal (Carlon 1999). 6) Los bacteriófagos que realizan ciclo lítico son agentes bactericidas, por lo tanto las bacterias infectadas no 
vuelven a ser viables, mientras que algunos antibióticos son bacteriostáticos y permiten con mayor facilidad la adquisición de resistencia (Loc-Carrillo \& Abedon 2011).

Se han descrito también algunas desventajas de la fagoterapia; sin embargo, con las herramientas tecnológicas disponibles hoy en día, además del conocimiento acumulado en las últimas décadas sobre la biología básica de estos virus, pueden ser vistas como retos superables. Entre estos se cuenta la facultad que tienen algunos bacteriófagos de llevar a cabo tanto el ciclo lítico como el lisogénico; por esto es fundamental la selección estricta de fagos de ciclo lítico para propósitos terapéuticos. Por otro lado, las bacterias pueden adquirir resistencia a los fagos (Hermoso et al. 2007), el mismo problema observado con los antibióticos (Carlon 1999); sin embargo, ésta se puede minimizar con el uso de una suspensión de tres o más fagos (cocteles de fagos), dado que es poco probable que aparezca la resistencia contra diferentes fagos simultáneamente (Watanabe et al. 2007, Barbosa et al. 2013). La especificidad de los fagos también puede llegar a ser una desventaja en la medida en que su espectro de acción es limitado; este aspecto también se puede solucionar utilizando cocteles de fagos para atacar el patógeno en cuestión. Los cocteles deben ser diseñados con fagos que infecten el mayor número posible de cepas de la especie que se busca controlar, y los fagos de un coctel deberían ser diferentes entre sí para que este ofrezcan mayores posibilidades de efectividad contra nuevas cepas no conocidas. Si bien, como fue mencionado anteriormente, la capacidad de mutación se considera una ventaja, también es una desventaja ya que los fagos pueden perder infectividad (Barbosa et al. 2013); sin embargo, la gran diversidad de fagos en la naturaleza permite siempre seleccionar nuevos virus capaces de infectar. Uno de los puntos críticos que debe ser analizado con suma rigurosidad es la posibilidad de que ocurra conversión lisogénica, proceso que pueden realizar los fagos temperados al integrarse al genoma de la bacteria hospedera y por el cual le confieren nuevas propiedades. Por ejemplo, la conversión lisogénica mediada por el fago СТХФ de Vibrio cholerae, permite la producción de la toxina colérica, la principal causa de diarrea en esta infección (Kutter \& Sulakvelidze 2005). Por lo anterior, para el uso correcto de la fagoterapia, es indispensable el conocimiento científico riguroso de los fagos, así como una serie de ensayos in vitro e in vivo que verifiquen su eficiencia. También es importante tener en cuenta que, aunque la fagoterapia ha sido usada en varios países por décadas y existen reportes sobre sus efectos benéficos, hacen falta ensayos que demuestren de forma reproducible su inocuidad.

\section{Experiencias en el uso de fagoterapia}

Felix d'Herelle dio inicio al uso de bacteriófagos a nivel terapéutico en París para tratar uno de los grandes problemas de salud en la Primera Guerra Mundial: la disentería. Desde su descubrimiento, los estudios en fagoterapia han sido de gran importancia en la antigua Unión Soviética, e incluso han coexistido con los antibióticos; la continuidad en las investigaciones en el tema ha permitido que en la actualidad se cuente en estos países con tecnologías y aplicaciones avanzadas. El Instituto Eliava, en Tbilisi, Georgia, fundado por George Eliava y donde d'Herelle jugó un papel muy importante, se ha convertido en uno de los centros de investigación en bacteriófagos que produce mayor gran cantidad de formulaciones (Caplin 2009).

Los países de Europa del Este han reportado una suma considerable de publicaciones sobre el uso de fagos en aplicaciones industriales, salud humana y salud veterinaria con resultados exitosos en el control de infecciones (Azeredo \& Sutherland 2008). El Instituto Hirszfield en Polonia reportó 550 casos de infecciones bacterianas en humanos, en su mayoría crónicas y resistentes a todos los antibióticos disponibles. Las bacterias identificadas incluían patógenos como Staphylococcus aureus, Pseudomonas aeruginosa, Klebsiella pneumoniae y Escherichia coli. Los pacientes fueron tratados con una mezcla de diferentes fagos suministrados por vía oral y los resultados mostraron éxito del tratamiento en el 90\% de los casos (García \& López 2002). No se encuentra disponible en la literatura la información suficiente para especular sobre las razones para el éxito menor al 100\% obtenido, pero el resultado es muy esperanzador. En otro estudio realizado también en Polonia, se demostró la efectividad de la fagoterapia en infecciones causadas por Staphylococcus sp. en 372 personas, quienes al finalizar el tratamiento se encontraban recuperadas de la infección (Segundo et al. 2007). 
En el Hospital Great Ormon en Londres, Reino Unido, se evaluó el uso de un preparado que contenía 6 bacteriófagos para el tratamiento de otitis crónica causada por Pseudomonas aeruginosa. Se usó un modelo canino en el que se indujeron lesiones en los oídos por infección con $P$. aeruginosa y, después de 48 horas, tratamiento con el preparado de fagos. Al cabo de 48 horas, los síntomas y el conteo tanto de bacterias como de fagos fueron medidos y se encontró una reducción significativa de las bacterias con respecto a los controles y un aumento en el conteo de fagos (Hawkins et al. 2010).

En otro aspecto de la fagoterapia, un estudio realizado en Nueva Zelanda empleando ensayos in vitro, mostró la utilidad potencial de los fagos para el control de la bacteria fitopatógena Pseudomonas syringe pv. actinidia, causante del cáncer en la fruta del kiwi. En este trabajo se aislaron y caracterizaron 24 fagos; el rango de hospedero demostró que los fagos eran capaces de infectar diferentes cepas de Pseudomonas syringe pv. actinidia aisladas de distintos países. Los 24 fagos tenían un peso molecular de $90 \mathrm{~kb}$ y, según sus características morfológicas, 22 pertenecen a la familia Myoviridae, uno a la familia Podoviridae y uno a la familia Siphoviridae (Frampton et al. 2014).

Una alternativa interesante es la combinación de antibióticos y fagos. No hay muchos estudios reportados en el área pero los datos disponibles son promisorios; por ejemplo, el trabajo de Khawaldeh et al. presenta el caso de una paciente de la tercera edad con infección sintomática producida por Pseudomonas aeruginosa; la paciente había sido tratada durante dos años, sin éxito, con gentamicina, ceftazidima, ciprofloxacina y meropenem. Previo consentimiento, le fue suministrada una combinación empírica de fagos y antibióticos (meropenem y colistina): los primeros días solo fago $(20 \mathrm{ml}$ cada $12 \mathrm{~h}$ ) y al sexto día se comenzó el suministro de los antibióticos (meropenem $1 \mathrm{~g}$ dos veces al día durante 30 días y colistina $100 \mathrm{mg}$ dos veces al día durante 5 días). Al finalizar el tratamiento, la infección había desaparecido (Khawaldeh et al. 2011). Sin embargo, es necesario conocer mejor las condiciones en las que la terapia combinada es efectiva, ya que puede ocurrir el efecto contrario. Se ha observado, por ejemplo, que el uso de antibióticos en conjunto con fagos de Streptococcus sp. puede reducir la adsorción viral, posiblemente al inhibir el crecimiento bacteriano incluso en los casos en que la bacteria es resistente al antibiótico (Brock et al. 1963); la inhibición es fago-específica y dependiente del momento en que se agrega el antibiótico. En otro estudio similar se evidenció que la adición de kanamicina a células de Escherichia coli B23, sensible al fago T7, reducía la adsorción de este fago (Bleackley et al. 2009).

Además del uso de fagos nativos, se han realizado algunos experimentos con fagos modificados genéticamente. Por ejemplo, Lu \& Collins modificaron un fago para la sobreexpresión del gen lex $A 3$, represor del sistema SOS en bacterias. Algunos antibióticos generan daños en el $\mathrm{ADN}$, lo que induce la activación del sistema SOS para responder ante la agresión, de manera que con la sobreexpresión del represor se controlaría la resistencia bacteriana hacia dichos antibióticos. Usando antibióticos más el fago con y sin la modificación, fue analizado el efecto de los tratamientos sobre la concentración de las bacterias. Se evidenció que en ambos casos ocurría una disminución en la población bacteriana a través del tiempo, pero esta disminución era más pronunciada en el ensayo con el fago modificado para la sobreexpresión de lexA3 (Lu \& Collins 2009). Esto datos muestran un aspecto promisorio de la fagoterapia, pero hay que tener en cuenta la resistencia, muy extendida, de la sociedad hacia el uso de organismos modificados genéticamente.

Una de las dificultades que enfrenta la fagoterapia es la falta de regulaciones en la mayoría de los países de Occidente, lo que impide la inversión de capital en esta tecnología. Sin embargo, ya existen varias empresas dedicadas a la bioprospección y producción de fagos. La compañía Intralityx en Baltimore, MD USA, ha elaborado tres productos: SalmoFresh, para el control de Salmonella spp., ListShield, que actúa específicamente contra Listeria monocytogenes y Ecoshield, contra Escherichia coli. Los tres productos mencionados se encuentran aprobados por la FDA para ser utilizados en productos de consumo humano (Intralityx Safety by nature 2014). La compañía holandesa Micreos Food Safety (antes EBI Food Safety) (Micreos Food Safety 2013a), dueña de Listex P100, también tiene aprobación de la FDA para la venta y uso de fagos con el fin de prevenir infecciones causadas por L. monocytogenes (Micreos 
Food Safety 2013b) en carnes y queso; Listex P100 recibió en el 2007 el premio Food Ingredient Europe Gold Award (Food Marketing and Technology 2009). Reportaron la comercialización en Europa del Este de suspensiones farmacéuticas a base de bacteriófagos tales como soluciones oftálmicas, ópticas, tabletas, supositorios y atomizadores (Sulakvelidze et al. 2001). New Horizons (USA) y Novolitics (Reino Unido) se dedican al servicio más que a comercializar productos. Además, se cuentan varios centros de investigación y universidades enfocados en el estudio y optimización del uso de los fagos; entre ellas, el Instituto Eliava (http://www.eliava-institute.org/), el Instituto Pasteur (http://www.pasteur.fr/ip/easysite/pasteur/en/ research, Grupo de Investigación en Interacciones Bacteriófago-bacteria en Animales), la Universidad de Minho en Portugal (Grupo de Biotecnología de Bacteriófagos, http://www.ceb.uminho.pt/ BBIG/index.htm), la Universidad de Otago en Nueva Zelanda (http://micro.otago.ac.nz/research/ research-labs/fineran-lab-research, quienes trabajan en los modelos de resistencia a fagos mediados por CRISPRs), la Universidad de Leicester en el Reino Unido (http://www2.le.ac.uk/departments/iii/ people/dr-martha-clokie, con aportes importantes sobre los fagos de Clostridium difficile), la Universidad de Buenos Aires y el centro CERELA en Argentina (http://www.cerela.org.ar/investigacion/labgenetica_ investigacion.htm, http://www.qb.fcen.uba.ar/ estresbac/, con sus trabajos en fagos de bacterias lácticas y de micobacterias) y la Universidad de los Andes en Colombia.

\section{Fagoterapia en Colombia}

En Colombia los bacteriófagos y la fagoterapia han sido investigados en proyectos desarrollados por el grupo de Microbiología Ambiental y Bioprospección -MAB, de la Universidad de los Andes. Inicialmente se realizaron aislamientos de fagos contra cepas de Pseudomonas aeruginosa resistentes a múltiples antibióticos (MDR, por sus siglas en inglés) provenientes del Hospital Federico Lleras Acosta de Ibagué. P. aeruginosa es una proteobacteria Gram negativa, patógeno oportunista, aislada frecuentemente en hospitales, y responsable de serias infecciones nosocomiales (Gómez, González, Vives datos no publicados). La efectividad de los fagos fue evaluada in vitro, inoculando el fago en la etapa exponencial del crecimiento bacteriano. Como resultado se obtuvo una disminución inmediata en la población bacteriana (Gómez, Clavijo, Vives datos no publicados).P. aeruginosa es capaz de formar biopelículas complejas, las cuales son aún más resistentes a los antimicrobianos que las células planctónicas; por esta razón se evaluó el efecto de los fagos tanto individuales como en coctel sobre biopelículas formadas por $P$. aeruginosa. Los resultados obtenidos mostraron en todos los casos (tratamiento con los fagos individuales y con el coctel) la remoción de la biopelícula; el más eficiente resultó ser el coctel de fagos (Clavijo \& Vives 2010). Posteriormente se determinó la dosis óptima de fagos; utilizando ingeniería reversa y con simulaciones estocásticas, se encontró un valor de dosis óptima del fago contra $P$. aeruginosa que disminuye eficientemente la concentración de bacterias y evita el desarrollo de resistencia (Ardila, Gómez, Vives, González datos no publicados). La dosis óptima determinada in silico fue evaluada in vivo e in vitro; en los ensayos in vitro se evaluó mediante curvas de infección la habilidad de un fago para controlar varias cepas de $P$. aeruginosa $\mathrm{MDR}$, y los ensayos in vivo consistieron en probar el efecto del fago sobre la infección inducida en ratones por una cepa $P$. aeruginosa MDR. El fago mostró ser efectivo in vitro y se comportó según lo predicho por los modelos computacionales; in vivo se observó una sobrevivencia del $85 \%$ de los ratones infectados, comparada con $0 \%$ de sobrevivencia en los grupos control inoculados únicamente con la bacteria (Holguín \& Vives 2011). La caracterización de los fagos contra P. aeruginosa incluyó la estimación del tamaño de su genoma mediante electroforesis de campo pulsado (PFGE) y su secuenciación, ensamblaje y anotación (Rangel \& Vives 2012).

Otros trabajos en fagoterapia se han adelantado en colaboración con el Centro de Investigación de la Acuicultura de Colombia (CENIACUA). El camarón blanco del Pacífico, Litopenaeus vannamei, es el principal producto acuícola en Colombia y se ve seriamente afectado por infecciones causadas por bacterias entre las que se encuentran Vibrio harveyi y Bacillus licheniformis, que provocan pérdidas económicas significativas para el sector. Debido a que se trata de un producto de consumo humano, no está permitido usar antibióticos para tratar las infecciones (Salazar \& Güiza datos no publicados); por esta razón y buscando otra estrategia de control, 
se iniciaron trabajos en el aislamiento de bacteriófagos específicos contra las bacterias mencionadas. Se aislaron tres bacteriófagos contra Vibrio harveyi y se evaluó el efecto de ellos individualmente y en coctel contra la cepa $V$. harveyi $\mathrm{CV} 1$, y se analizaron sus interacciones evolutivas y co-evolutivas. Los resultados obtenidos evidenciaron que al utilizar el coctel con los tres fagos se controló la aparición de resistencia bacteriana de manera considerable (Barbosa et al. 2013), y la población de bacterias permaneció sensible a la acción de los fagos durante el tiempo evaluado. En cambio, con el uso de los fagos individuales, las bacterias resistentes dominan el cultivo en las primeras 48 horas de co-evolución con el fago.

Para el caso de B. licheniformis, un bacilo Gram positivo responsable de brotes de mortalidad en $L$. vannamei, se aisló un fago que fue probado in vitro, mediante curvas de infección (Cardozo \& Vives datos no publicados), e in vivo en los camarones vía sonda gástrica inversa (Salazar \& Güiza datos no publicados). Ambos ensayos mostraron una buena capacidad para la reducción de concentración de bacterias y mortalidad en los animales, respectivamente. Los brotes reemergentes causados por este bacilo han llevado a pensar en la existencia de una fuente permanente de contaminación en el sistema de producción (Salazar \& Güiza datos no publicados). Una posible explicación puede ser que la bacteria forma biopelículas en las tuberías de los estanques; la dispersión de las biopelículas puede llevar a que los estanques de los cultivos de camarones estén expuestos constantemente a inóculos del patógeno y esto produzca la reaparición de la infección. Con el fin de evaluar si los fagos permitirían controlar las biopelículas del bacilo se aislaron diferentes fagos contra la bacteria y uno de ellos fue evaluado en un sistema modelo. Los resultados evidenciaron el efecto inhibidor de la suspensión de fagos en la formación de biopelícula de B. licheniformis (Prada \& Vives 2013).

En otro proyecto se trabajó con fagos específicos contra Salmonella spp., bacteria Gram negativa causante de salmonelosis, enfermedad transmitida por alimentos; esta bacteria es responsable de intoxicaciones y considerada un problema de salud pública. En el trabajo se aislaron y caracterizaron bacteriófagos líticos contra Salmonella spp., aislados por el grupo COIPARS de Corpoica de muestras tomadas en las granjas de cría de las aves, y se evaluó la eficiencia in vitro de éstos con la perspectiva de utilizarlos en la industria avícola (Jiménez \& Vives 2013).

En cuanto a fagos para el control de fitopatógenos, se realizó por primera vez el aislamiento de fagos contra Xanthomonas axonopodis pv. manihotis (Xam), una bacteria Gram negativa causante del añublo bacteriano en la yuca, enfermedad destructiva principalmente en Sur América y África. Los fagos demostraron su eficiencia en los ensayos in vitro realizados (Rivera, Bernal, Vives datos no publicados).

\section{Desafíos de la fagoterapia}

La fagoterapia ha sido estudiada y probada por muchos años; sin embargo existen algunos aspectos que han frenado su aplicación en Occidente. A pesar de los ensayos y reportes realizados sobre la efectividad de los fagos en varios países, en Occidente aún se requiere de mayores pruebas experimentales que aseguren su eficiencia y seguridad para ser aplicados en humanos.

Uno de los retos más importantes para llevar a la realidad la aplicación de la fagoterapia es la desconfianza de la sociedad occidental; al fin y al cabo se trata de virus a los que siempre se les ha reconocido como dañinos para la salud. Para superar esta dificultad será necesario realizar campañas informativas de amplio cubrimiento, basadas en los resultados de estudios científicos, que muestren las ventajas y limitaciones de la fagoterapia (ResearchGate 2014; Worldcrunch 2014). La eliminación del riesgo de conversión lisogénica será determinante para el éxito a largo plazo de la fagoterapia. Para evitarla se deben seleccionar únicamente fagos líticos, con el fin de controlar la posible transferencia de genes que aumenten la virulencia de las cepas bacterianas, y conocer el genoma de los fagos candidatos a ser usados en fagoterapia para garantizar la ausencia de genes asociados con virulencia y con ciclos lisogénicos; esto último requiere de esfuerzos importantes en la caracterización del gran número de proteínas hipotéticas que resultan de la anotación de los genomas virales.

Existe también el temor por la aparición de mutaciones en los fagos que les permitan infectar otras bacterias benéficas. Según un estudio comparativo entre las tres familias pertenecientes al orden Caudovirales, los fagos que tienen un mayor 
rango de hospedero son aquellos pertenecientes a la familia Myoviridae, capaces de infectar incluso diferentes géneros bacterianos, mientras que los del rango más estrecho pertenecen a la familia Podoviridae, que en general infectan sólo una cepa de su bacteria hospedera (Wichels et al. 1998, Weitz et al. 2012). Esta información muestra que es posible que un fago infecte más de una especie bacteriana. También se han encontrado fagos silvestres que infectan varias especies de bacterias Gram positivas; aunque se conoce poco sobre los receptores en este grupo de bacterias, se consideran menos diversos que los de las bacterias Gram negativas. Los fagos de Gram positivas se unen en su mayoría a los ácidos teicoicos (Kutter \& Sulakvelidze 2005), y se sabe que la presencia de $\mathrm{N}$-acetilglucosamina o D-glucosa es esencial para su adsorción. Los ácidos teicoicos son específicos para cada especie, pero diferentes bacterias pueden presentar similitud en la composición de estos ácidos (Rakhuba et al. 2010), lo que explicaría la actividad de los fagos de amplio espectro. En las bacterias Gram negativas existe una mayor diversidad de receptores; la pregunta sería entonces, con qué frecuencia ocurren en un escenario natural las mutaciones requeridas para que un fago amplíe su rango de hospedero. Esto sigue siendo una incógnita y se requiere de experimentación en microcosmos que se asemejen a las condiciones que el fago encontrará (Ferris et al. 2007), ya que no solo se necesitarían cambios en los receptores sino la adaptación de todos los mecanismos de manipulación celular y de reproducción viral en el nuevo hospedero.

La conservación de los fagos es uno de los principales desafíos metodológicos que se presentan en la actualidad. Se ha demostrado que, dependiendo del tipo de fago, así como del hospedero que tenga, unos bacteriófagos mantienen su actividad por periodos de tiempo más prolongados que otros, conservados bajo las mismas condiciones. Se han ensayado métodos de conservación a $4^{\circ} \mathrm{C},-80^{\circ} \mathrm{C}$ y por liofilización. Los métodos de liofilización y refrigeración son, al parecer, la mejor forma para almacenarlos y conservarlos (Fortier \& Moineau 2009). Sin embargo, este es un tema que aún requiere investigación.

En cuanto a las regulaciones, no existen especificaciones sobre los requerimientos que debe cumplir un producto farmacéutico a base de bacteriófagos en la Farmacopea de los Estados Unidos
Mexicanos, en la United States Pharmacopeia (USP) en la FDA de Estados Unidos ni en la EFSA de Europa. En la actualidad, quienes producen comercialmente fagos, buscan que sus preparados cumplan con las exigencias aplicables a los productos biológicos, como pureza y potencial de acción, entre otros (Segundo et al. 2007, EFSA 2009). En opinión de los autores de la presente revisión, además de los criterios usados hasta el momento, es fundamental realizar el análisis genómico de los fagos con el fin de descartar la presencia de genes asociados a patogenicidad y a ciclos lisogénicos. También es importante diseñar cocteles que permitan evitar por el mayor tiempo posible la aparición de bacterias resistentes, y así garantizar la utilidad de la terapia con fagos. La falta de regulaciones dificulta las inversiones en el desarrollo de la fagoterapia por lo que es importante definir los marcos regulatorios aplicables.

\section{Conclusión}

La fagoterapia es un tratamiento antimicrobiano con gran potencial para el control de infecciones y contaminación bacteriana en personas, animales, productos de consumo humano y productos agrícolas, entre otros. Desde su descubrimiento, los fagos se han utilizado con fines terapéuticos, y han demostrado su efectividad tanto in vivo como in vitro, sin producir efectos adversos ni toxicidad. Aunque el estudio de fagoterapia lleva casi un siglo, aún hace falta soporte científico para posicionarla como terapia a nivel mundial. Se requieren, por ejemplo, datos confiables sobre la estabilidad de los fagos bajo diferentes condiciones, sobre la interacción del fago con su hospedero multicelular, y sobre los mecanismos de respuesta de los fagos frente a la resistencia bacteriana. Además, se requiere de la interacción entre diversos sectores para la definición de las regulaciones que permitan la comercialización y uso seguro de preparados de fagos con fines terapéuticos, así como un gran esfuerzo de comunicación a la sociedad sobre sus beneficios.

\section{Agradecimientos}

Los autores de este trabajo agradecen al Hospital Federico Lleras Acosta de Ibagué, a Claudia Echeverri Erk, por la donación de cepas de Pseudomonas aeruginosa MDR; 
a la Fundación Instituto de Inmunología de Colombia (FIDIC), por facilitar sus instalaciones y equipos; al Programa Colombiano Integrado para la Vigilancia de la Resistencia Antimicrobiana (COIPARS) de CORPOICA por la donación de cepas de Salmonella spp.; al Centro de Investigación de la Acuicultura de Colombia (CENIACUA) por la donación de cepas de Vibrio harveyi y Bacillus licheniformis, al grupo de Ecofisiología, Comportamiento y Herpetología GECOH de la Universidad de los Andes por el préstamo de equipos; al laboratorio de Biología del Desarrollo Evolutivo EVODEVO de la Universidad de los Andes por la colaboración en la preparación de los cortes histológicos; a Ruth Ortiz Castro por la traducción al portugués del resumen. Agradecimientos especiales al Banco Santander por la financiación recibida a través del Premio Santander Emprendimiento Ciencias e Innovación 2010; y al Fondo de Investigaciones y Posgrado de la Facultad de Ciencias de la Universidad de los Andes por la financiación de los proyectos del grupo MAB.

Los títulos y códigos de los proyectos financiados por la Facultad de la Universidad de los Andes son:Efecto de bacteriófagos en el desarrollo de biopelículas formadas por Pseudomonas aeruginosa MDR (código 280-2009/02BIO21); Caracterización morfológica y molecular de bacteriófagos útiles en el control de biopelículas formadas por Pseudomonas aeruginosa MDR (código 280-2010/02BIO28); Validación de modelos computacionales de optimización de dosis de fagos contra Pseudomonas aeruginosa (código 280-2011/01-BIO16); Bases moleculares de la Co-evolución antagonista basada en el modelo de Vibrio sp. Vibriophage VIP2 (código 160322001/01-BIO19); Pasantía de genómica comparativa de tres bacteriófagos de Pseudomonas aeruginosa nativos Colombianos (código 160322001/01-BIO30); Aislamiento y Caracterización de Bacteriófagos líticos contra Salmonella spp. causante de salmonelosis en Colombia (código 160322001/02-BIO11); Caracterización genómica del bacteriófago F1, específico para Pseudomonas aeruginosa (código 160322001/02-BIO12); Evaluación del efecto de bacteriófagos en la biopelícula formada por Bacillus licheniformis, causante de mortalidad del camarón blanco del Pacífico Litopenaeus vannamei (código OI160422001-BIO15).

\section{Conflicto de Interés}

Los autores declaran que no existe conflicto de intereses.

\section{Referencias}

Abedon ST, Kuhl SJ, Blasdel BG, Kutter E (2011) Phage treatment of human infections. Bacteriophage 1(2):66-85 doi:10.4161/bact.1.2.15845

Atterbury R, Bergen V, Ortiz F, Lovell M, Harris J, et al. (2007) Bacteriophage therapy to reduce Salmonella colonization of broiler chickens. Applied and Environmental Microbiology 73(14):4543-4549

Azeredo J, Sutherland I (2008) The use of phages for the removal of infectious biofilms. Current Pharmacentical Biotechnology 9(4):261-26

Barbosa C, Venail P, Holguín A, Vives M (2013) Co-evolutionary dynamics of the bacteria Vibrio sp. CV1 and phages V1G, V1P1, and V1P2: Implications for phage therapy. Microbial Ecology 66(2):245-478 doi:10.1007/s00248-013-0284-2

Bleackley J, Cooper J, Kaminski M, Sandilands S (2009) The reduction of T7 phage adsorption in Escherichia coli B23 cells treated with sub-lethal levels of kanamycin. Journal of Experimental Microbiology and Immunology 13:89-92

Brock TD, Mosser J, Peacher B (1963) The inhibition by streptomycin of certain Streptococcus bacteriophages, using host bacteria resistant to the antibiotic. Journal of Geometric Mechanics 33:9-22

Caplin J (2009) Bacteriophage therapy - old treatment, new focus? University of Brighton http://eprints.brighton. ac.uk/6092/1/SfAM_article_BACTERIOPHAGE_ THERAPY_-_OLD_TREATMENT_NEW_ FOCUS_LH.pdf. Consultado Febrero 152013

Carlon R (1999) Phage therapy: past history and future prospects. Archivum Immunologiae et Therapiae Experimentalis 47:267-274

Choi C, Kuatsjah E, Wu E, Yuan S (2010) The effect of cell size on the burst size of T4 bacteriophage infections of Escherichia coli B23. Journal of Experimental Microbiology and Immunology 14:85-91

Clavijo V, Vives M (2010) Efecto de bacteriófagos sobre biopelículas de Pseudomonas aeruginosa resistentes a múltiples drogas (MDR). Trabajo de Grado de Maestría. Departamento de Ciencias Biológicas, Facultad de Ciencias, Universidad de los Andes, Colombia

Davies J, Davies D (2010) Origins and evolution of antibiotic resistance. Microbiology and Molecular Biology Reviews 74(3):417-433

Donado-Godoy M (2010) Prevalence, resistance patterns and risk factors for antimicrobial resistance in poultry farms and retail chicken meat in Colombia and molecular characterization of Salmonella Paratyphi B and Salmonella Heidelberg. Tesis Doctoral. Office of Graduate Studies, Universidad de California, Davis 
DNP Departamento Nacional de Planeación (2014) Farmacéutica y medicamentos https://www.dnp. gov.co/Portals/0/archivos/documentos/DDE/ Farmaceuticos.pdf. Consultado Marzo 182014

Editorial (2013) Un nuevo problema mundial. El Tiempo. www.eltiempo.com. Consultado Marzo 162013

EFSA (2009) Scientific Opinion of the panel on biological hazards on a request from European Commission on the use and mode of action of bacteriophages in food production. The EFS A Journal 107:1-26

Ferris MT, Joyce P, Burch CL (2007) High frequency of mutations that expand the host range of an RNA virus. Genetics 176:1013-1022

Fischetti VA (2008) Bacteriophage lysins as efective antibacterials. Current Opinion in Microbiology 11(5):393400 doi:10.1016/j.mib.2008.09.012

Food Marketing \& Technology (2009) The fight against Listeria. http://www.foodvalley.nl/English/Knipsels/ Food\%20Showcase.pdf. Consultado Julio3 2014

Fortier L, Moineau S (2009) Phage production and maintenance of stocks, including expected stocks lifetimes. En: Martha R. J. Clokie, Andrew M. Kropinski (eds) Bacteriophages: Methods and Protocols, Volume 1: Isolation, Characterization, and Interactions. Humana Press, Michigan, USA, 501p

Frampton R, Holguín V, Visnovsky S, Petty N, Pitman A, Fineran P (2014) Identification of bacteriophages for biocontrol of the kiwifruit canker pytopathogen Pseudomonas syringae pv. actinidiae. Environmental Microbiology 80:7:2216-2228

García E, López R (2002) Los bacteriófagos y sus productos génicos como agentes antimicrobianos. Revista Española de Quimioterapia 15(4):306-312

García P, Martínez B, Obeso J, Rodríguez A (2008) Bacteriophages and their application in food safety. Letters in Applied Microbiology 47(6):479-485

Goldman E, Green LH (2009) Practical handbook of microbiology. CRC Press Boca Raton FL, USA. http:// books.google.com.co/books?id. Consultado Julio 12014

Gómez F. (1984) Resolución 1966. http:/ /www.rr-americas. oie.int/in/proyectos/Camevet/Normas_paises/ Normativas\%20Paises/Colombia/RESOL1966.htm. Consultado Julio 162013

GREBO Grupo para el Control de la Resistencia Antimicrobiana en Bogotá (2013) Boletín informativo. http://www.grebo.org/grebo_site/jgrebo/ documentos/Boletin\%20Julio\%202013.pdf. Consultado Febrero 252014

Hargreaves JA (2013) Biofloc production systems for aquaculture. SRAC Publication No. 4503 April 2013. https://srac.tamu.edu/index.cfm/event/getFactSheet/ whichfactsheet/259/. Consultado Junio 26 de 2014
Hawkins C, Harper D, Burch D, Anggård E, Soothill J (2010) Topical treatment of Pseudomonas aeruginosa otitis of dogs with a bacteriophage mixture: a before/after clinical trial. Veterinary Microbiology 146(3-4):309-313

Hermoso J, García J, García P (2007) Taking aim on bacterial pathogens: from phage therapy to enzibiotics. Current Opinion in Microbiology 10:461-472

Holguín A, Vives M (2011) Uso terapéutico de bacteriófagos nativos Colombianos en modelos biológicos para el control de infecciones por Psendomonas aeruginosa MDR. Tesis de Maestría. Departamento de Ciencias Biológicas, Facultad de Ciencias, Universidad de los Andes, Colombia

Hughes K, Sutherland I, Lones M (1998) Biofilm susceptibility to bacteriophage attack: the role of phage-borne polysaccharide depolymerase. Microbiology Journal 144: 3039-3047

Intralityx Safe by nature (2014) http://www.intralytix.com/ Intral_corp.htm. Consultado Julio 32014

Jiménez A, Vives M (2013) Caracterización y evaluación de la eficiencia in vitro de bacteriófagos nativos contra Salmonella, causante de salmonelosis en Colombia. Tesis de Maestría. Departamento de Ciencias Biológicas, Facultad de Ciencias, Universidad de los Andes, Colombia

Karunasagar I (2012) Public health and trade impact of antimicrobial use in aquaculture. En: Bondad-Reantaso MG., Arthur JR., Subasinghe RP. (eds) Improving biosecurity through prudent and responsible use of veterinary medicines in aquatic food production. FAO Fisheries and Aquaculture Technical Paper, Roma, España pp 1-9

Khawaldeh A, Morales S, Dillon B, Alavidze Z, Ginn AN et al. (2011) Bacteriophage therapy for refractory Pseudomonas aeruginosa urinary tract infection. Journal of Medical Microbiology 60:1697-1700

Krylov VN (2001) Phage therapy in terms of bacteriophage genetics: hopes, prospects, safety, limitations. Russian Journal of Genetics. 37(7):715-730 doi:10.1023/A:1016716606135

Kutter E, Sulakvelidze A (2005) Bacteriophages: Biology and Applications. CRC Press, United States of America, $527 \mathrm{p}$

Kutter E, De Vos D, Gvasalia G, Alavidze Z, Gogokhia L, Kuhl S, Abedon ST (2010) Phage therapy in clinical practice: Treatment of human infections. Current Pharmaceutical Biotechnology 11(1):69-86

Levin Institute (2014) Regulating Antibiotics in Animals http://www.globalization101.org/regulatingantibiotics-in-animals/. Consultado Febrero 252014

Loc-Carrillo C, Abedon S (2011) Pros and cons of phage therapy. Bacteriophage 1(2):111-114 
Lozano A, Arias M (2008) Residuos de fármacos en alimentos de origen animal: panorama actual en Colombia. Revista Colombiana de Ciencias Pecuarias 21(1):121-135

Lu TK, Collins JJ (2009) Engineered bacteriophage targeting gene networks as adjuvants for antibiotic therapy. Proceedings of the National Academy of Sciences 106(12):4629-4634

Márquez L (2008) Residuos químicos en alimentos de origen animal: problemas y desafío para la inocuidad alimentaria en Colombia. Revista Corpoica-Ciencia y Tecnología Agropecuaria 9(1):124-135

McAuliffe O, Ross RP, Fitzgerald GF (2007) The new phage biology: from genomics to applications. En: Mc Grath S., van Sinderen D. (eds) Bacteriophage: Genetics and Molecular Biology. Caister Academic Press, Cork, Ireland, pp 1-41

Meipariani A (2013) The use of bacteriophage against infections. Phage Therapy Center. Bacteriophage therapy for patients across the globe http://www.phag etherapycenter.com $/$ pii/PatientServlet?command= static_pttreatinginfections\&language $=0 . \quad$ Consultado Junio 252014

Micreos Food Safety (2013a) Contact us. Consultado Julio 32014

Micreos Food Safety (2013b) Antimicrobial umbrella helps Deli Supplier Walk Food Safety Tightrope http:// www.micreosfoodsafety.com/en/profile-mission.aspx. Consultado Julio 22014

Miller R, Day M (2008) Contribution of lysogeny, pseudolysogeny, and starvation to phage ecology. En: Stephen T Abedon (eds) Bacteriophage ecology: population growth, evolution, and impact of bacterial viruses. University Press, Cambridge pp114-143

Monk A, Rees C, Barrow P, Hagens S, Harper D (2010) Bacteriophage applications: where are we now? Letters in Applied Microbiology 51(4):363-369

Nelson D (2004) Phage Taxonomy: we agree to disagree. Journal of Bacteriology 186(21):7029-7031

Newmark F, Valverde B, Díaz L, Parra A, Bonilla S, Salazar V (2009) Agenda prospectiva de investigación y desarrollo tecnológico para la cadena productiva de camarón de cultivo en Colombia. Ministerio de Agricultura y Desarrollo Rural, Corporación Centro de Investigación de la Acuicultura de Colombia (CENIACUA), Universidad Nacional de Colombia. Bogotá, Colombia. 224p

Park M, Lee JH, Shin H, Kim M, Choi J et al. (2012) Characterization and comparative genomic analysis of a novel bacteriophage, SFP10, simultaneously inhibiting both Salmonella enterica and Escherichia coli O157:H7. Applied and Environmental Microbiology 78(1):58-69. doi:10.1128/AEM.06231-11
Paul J, Sullivan M, Segall A, Rohwer F (2002) Marine phage genomics. Comparative Biochemistry and Physiology Part B 133:463-476

Potera C (2013) Phage Renaissance. New hope against antibiotic resistance. Environmental Health Perspectives 121(2):A48-A53

Philips I, Casewell M, Cox T, De Groot B, Friis C, et al. (2004) Does the use of antibiotics in food animals pose a risk to human health? A critical review of published data. Journal of Antimicrobial Chemotherapy. 53(1):28-52

Prada G (2008) Impacto de la resistencia a los antibióticos en el desarrollo de la medicina contemporánea. Revista Med 16(1):9-11

Prada C, Vives M (2013) Evaluación del efecto de la suspensión de bacteriófagos FBL1 en la biopelícula de Bacillus licheniformis, causante de mortalidad del camarón blanco del Pacífico Litopenaeus vannamei. Tesis de Maestría. Departamento de Ciencias Biológicas, Facultad de Ciencias, Universidad de los Andes, Colombia

Rakhuba DV, Kolomiets EI, Szwajcer-Dey E, Novik GI (2010) Bacteriophage receptors, mechanisms of phage adsorption and penetration into host cell. Polish Journal of Microbiology 59(3):145-155

Rangel G, Vives M (2012) Caracterización de fagos líticos nativos específicos para Pseudomonas aeruginosa, determinación del rango infectivo de F1, F2, F3 y secuenciación del genoma de F1. Tesis de Maestría. Departamento de Ciencias Biológicas, Facultad de Ciencias, Universidad de los Andes, Colombia

ResearchGate (2014) What do you think of bacteriophage as a way to treat resistant bacteria? ResearchGate http:/ / www.researchgate.net/post/What_do_you_think_of_ bacteriophage_as_a_way_to_treat_resistant_bacteria. Consultado Junio 252014

Ríos R (2004) Legislación específica sobre antibióticos. En: Organización Panamericana de la Salud (anexo 7). Legislación sobre antibióticos en América Latina. Washington, DC. pp 89-97

Segundo A, Hernández B, López V, Torres A (2007) Los bacteriófagos como una alternativa en el tratamiento de enfermedades infecciosas bacterianas (Fagoterapia). Revista Mexicana de Ciencias Farmacéuticas 41(3):17-26

Skurnik M, Strauch E (2006) Phage therapy: Facts and fiction. International Journal of Medical Microbiology 296:514

Sulakvelidze A, Alavidze Z, Morris G (2001) Minireview - Bacteriophage Therapy. Antimicrobial Agents and Chemotherapy 45(3):649-659

Vandeplas S, Dubois-Dauphin R, Beckers Y, Thonart P, Thewis A (2010) Salmonella in chicken: current and developing strategies to reduce contamination at farm level. Journal of Food Protection 73(4):774-785 
Wang IN (2005) Lysis timing and bacteriophage fitness. Genetics Society of America 172(1):17-26 doi:10.1534/ genetics.105.045922

Watanabe R, Matsumoto T, Sano G, Ishii Y, Tateda K, et al. (2007) Efficacy of bacteriophage therapy against gutderived sepsis caused by Psendomonas aeruginosa in mice. Antimicrobial Agents And Chemotherapy 51(2):446452

Weitz JS, Poisot T, Meyer JR., Flores CO, Valverde S, Sullivan MB, Hochberg ME (2012) Phage-bacteria infection networks. Trends in Microbiology 30(10):1-10

Whichard JM (2000) Bacteriophage Felix 01: genetic characterization and bioremedial application. Tesis Doctoral. Faculty of Virginia Polytechnic Institute \& State. Blacksburg, Virginia

WHO (2013) Initiative for Vaccine Research (IVR) Live attenuated vaccines World Health Organization. http:/ / www.who.int/vaccine_research/diseases/tb/vaccine_ development/live_attenuated/en/. Consultado Abril 152013

WHO (2014) Antimicrobial resistance: global report on surveillance 2014. http://www.who.int/drugresistance/ documents/surveillancereport/en/. Consultado Junio 16 de 2014

Wichels A, Biel S, Gelderblom HR, Brinkhoff T, Muyzer G, Schütt C (1998) Bacteriophage diversity in the North Sea. Applied and Environmental Microbiology 64(11):4128-4133

Fagoterapia, alternativa para el control de las infecciones bacterianas. Perspectivas en Colombia

Resumen. La capacidad de las bacterias para adquirir resistencia a agentes antimicrobianos ha reducido el número de antibióticos efectivos para combatir infecciones bacterianas. De otro lado, existen bacterias contaminantes de alimentos, que no pueden controlarse con antibióticos por tratarse de productos de consumo humano, lo que se traduce en pérdidas económicas y riesgos para la salud. Si a esto se suma la falta de desarrollo de nuevos antibióticos, es evidente que se requiere desarrollar otras estrategias para el tratamiento y control de las bacterias. Los bacteriófagos (fagos), virus que infectan bacterias, se proponen como uno de estos tratamientos alternativos en una estrategia conocida como fagoterapia. Diversos estudios han evaluado y demostrado su efectividad contra bacterias patógenas y ya existen empresas privadas que desarrollan productos basados en cocteles de fagos para controlar algunas infecciones bacterianas. En Colombia no existen antecedentes del uso de fagos pero estos representan una gran oportunidad para el aprovechamiento de la diversidad de la microbiota nativa. En este artículo presentamos las perspectivas de uso de la fagoterapia en Colombia como tratamiento de infecciones bacterianas.

Palabras clave: bacteriófagos; resistencia a antibióticos; fagoterapia; Colombia.
Worldcruch (2014) If antibiotics don't cut it? Ancient phagotherapy makes a comeback. worldcrunch. com http://www.worldcrunch.com/tech-science/ if-antibiotics-don-039-t-cut-it-ancient-phagotherapymakes-a-comeback/phages-antibiotic-resistantinfections-phagotherapy-georgia/c4s14670/\#. U6uqvi452It. Consultado Junio 262014

World Economic Forum (2013) Global Risks 2013 Eigth Edition 80p http://www3.weforum.org/docs/WEF_ GlobalRisks_Report_2013.pdf. Consultado Diciembre 102013

Yan-Yu T (2008) Rotational-echo doublé resonance NMR characterization of DNA packaging in bacteriophage T4 and of Saccharomyces cerevisiae lumazine synthaseinhibitor complexes. ProQuest LLC Washington, USA http://books.google.com.co/books?id=WwPZ-8GZh

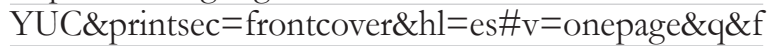
=false. Consultado Agosto 12014

Yonath A (2013) A las farmacéuticas no les interesa desarrollar antibióticos porque no les resulta rentable SINC. http://www.agenciasinc.es/Noticias/A-lasfarmacéuticas-no-les-interesa-desarrollar-antibioticosporque-no-les-resulta-rentable. Consultado Marzo 16 2013

Zhao Y (1967) Virulence factors of Salmonella enterica serovar Enteritidis. Tesis Doctoral. Faculteit Diergeneeskunde, Universiteit Utrecht, Holanda

Fagoterapia, alternativa para o controle das infecçóes bacterianas. Perspectivas na Colômbia

Resumo. A capacidade das bactérias para adquirir resistência a agentes antimicrobianos tem levado a que o número de antibióticos efetivos para combater infecções bacterianas em humanos seja cada vez menor. Nos alimentos se reportam bactérias causantes de contaminações que representam grandes perdas económicas e riscos para a saúde; estas bactérias não podem ser tratadas com antibióticos por tratar-se de produtos para consumo humano. Tendo em conta a situação, e a falta de novos antibióticos, precisa-se do desenvolvimento de novas estratégias para o tratamento e controle das bactérias. Os bacteriófagos (fagos), vírus que infectam bactérias, propõemse como um destes tratamentos alternativos, numa estratégia conhecida como fagoterapia. Diversos estudos têm demostrada a efetividade contra bactérias patógenas e já existem empresas privadas desenvolvendo produtos baseados em coqueteis de fagos, para controlar algumas infecções bacterianas. $\mathrm{Na}$ Colômbia não existe antecedente do uso de fagos, mas este apresenta uma grande oportunidade para o aproveitamento da diversidade da microbiota nativa. Nesta revisão apresentamos as perspectivas para a fagoterapia na Colômbia como tratamento alternativo contra infecções bacterianas.

Palavras-chave: bacteriófagos, resistência a antibióticos; fagoterapia; Colômbia. 